\title{
SPRAWOZDANIA I KOMUNIKATY
}

\section{Sprawozdanie z Konferencji Polskiego Towarzystwa Neofilologicznego Koncepcje i wdrożenia w glottodydaktyce - Sosnowiec 2009}

W dniach 7-9 września 2009 odbyła się w Sosnowcu doroczna konferencja naukowa Polskiego Towarzystwa Neofilologicznego, zorganizowana wspólnie przez Zarząd Główny PTN i Instytut Języków Romańskich i Translatoryki Uniwersytetu Śląskiego. Honorowy patronat nad spotkaniem objęli: JM Rektor Uniwersytetu Śląskiego prof. zw. dr hab. Wiesław Banyś, Wojewoda Śląski Zygmunt Łukaszczyk, Marszałek Województwa Śląskiego Bogusław Śmigielski oraz Prezydent Miasta Sosnowca Kazimierz Górski.

Zaproszenia do Komitetu Naukowego konferencji przyjęli: prof. dr hab. Anna Niżegorodcew (UJ Kraków), prof. dr hab. Teresa Siek-Piskozub (UAM Poznań), prof. dr hab. Weronika Wilczyńska (UAM Poznań), prof. dr hab. Krystyna Wojtynek-Musik (UŚ Sosnowiec), prof. dr hab. Maria Wysocka (UŚ Sosnowiec), prof. dr hab. Elżbieta Zawadzka-Bartnik (UW Warszawa), prof. UAM dr hab. Anna Cieślicka (UAM Poznań), prof. UAM dr hab. Krystyna Droździał-Szelest (UAM Poznań), prof. UAM dr hab. Katarzyna Karpińska-Szaj (UAM Poznań), prof. UWr dr hab. Anna Michońska-Stadnik (UWr Wrocław), prof. UAM dr hab. Mirosław Pawlak (WP-A UAM Kalisz).

Nad przygotowaniem i przebiegiem konferencji czuwał Komitet Organizacyjny w składzie: prof. dr hab. Halina Widła (Przewodnicząca PTN, Przewodnicząca Komitetu Organizacyjnego), dr Aneta Chmiel (IJRiT UŚ, PTN), mgr Beata Gałan (IJRiT UŚ, PTN), mgr Renata Klimek-Kowalska (PTN), dr Grzegorz Markowski (IJRiT UŚ, PTN), dr Jerzy Nykiel (IJRiT UŚ), mgr Sławomir Smugowski (IJRiT UŚ), dr Monika Sułkowska (IJRiT UŚ, P'TN).

Tegoroczna konferencja miała wyjątkowo uroczysty charakter ze względu na jubileusz 80. lecia powstania Polskiego Towarzystwa Neofilologicznego. Z tej okazji, podczas otwarcia konferencji refleksjami na temat PTN podzielili się: Dennis Cunnigham, Sekretarz Generalny FIPLV, prof. UŚ dr hab. Halina Widła, Przewodniczaca PTN, prof. UAM dr hab. Mirosław Pawlak, Sekretarz Generalny PTN. Jubileuszowi poświęcony też był wieczór wspomnień członków PTN w trakcie którego zaprezentowano specjalnie przygotowaną na tę okazję publikację Polskie Towarzystwo Neofilologiczne 1929-2009 (Katowice 2009), w opracowaniu Zofii Magnuszewskiej i Haliny Maleńczyk-Boguszewskiej, przedstawiającą bogatą historię i osiagnięcia PTN na przestrzeni ostatnich 80. lat.

W konferencji i towarzyszacym jej warsztatach wzięło łącznie udział 213 osób, głównie członków PTN ze wszystkich oddziałów krajowych, a także gości i osób niezrzeszonych. Obrady odbywały się w nowoczesnym, świetnie wyposażonym budynku Wydziału Filologicznego Uniwersytetu Śląskiego w Sosnowcu.

W trakcie konferencji wygłoszono 88 referatów, a wystąpienia prelegentów, skupione wokół tematu przewodniego Koncepcje i wdrożenia w glottodydaktyce, dotyczy- 
ły takich zagadnień szczegółowych jak: badania ilościowe i jakościowe w glottodydaktyce, badania empiryczne w studiach nad przyswajaniem języka obcego u dzieci, wielojęzyczność, metody gromadzenia danych, tożsamość nauczyciela, specjalne potrzeby edukacyjne, jednostki analizy w badaniach glottodydaktycznych, metodologia w konstruowaniu kursu języka dla potrzeb specjalistycznych, dziennik jako narzędzie badawcze, metody badania strategii u uczących się, korpus danych w badanich nad akwizycją języka obcego.

W wykładach plenaranych postawiono ważne pytania dotyczące kwestii autonomii oraz zakresu badań glottodydaktyki jako dziedziny naukowej: $W$ poszukiwa-

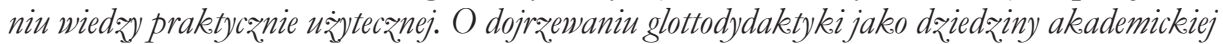
(prof. dr hab. Maria Dakowska, UW), Obszary badawcze glottodydaktyki (prof. dr hab. Weronika Wilczyńska, UAM).

Po raz kolejny konferencji PTN obradom w sekcjach towarzyszyły cieszące się ogromnym powodzeniem warsztaty. W trakcie odbywających się w czterech grupach językowych (j. angielski, j. niemiecki, j. francuski, j. włoski) warsztatów, uczestnicy mogli zapoznać się z najnowszymi pomocami dydaktycznymi on-line dla nauczycieli języków obcych.

Konferencja przebiegła w przyjaznej atmosferze, zaś wieczór bankietowy w restauracji Oko Miasta, w centrum Katowic, pozwolił uczestnikom na dodatkowe spotkania i rozmowy, a także na wysłuchanie koncertu szant w wykonaniu grupy BananaBoat.

Na zakończenie konferencji odbył się panel dyskusyjny wokół tematu głównego konferencji Koncepcje $i$ wdrożenia w glottodydaktyce. Panel, prowadzony przez prof. Halinę Widłę, był okazją do podsumowania tej niezwykle owocnej konferencji i zaproszenia uczestników do udziału w kolejnej konferencji PTN, która odbędzie się w roku 2010 w Lublinie.

Wymiernym efektem konferencji w Sosnowcu będą publikacje (trzy kolejne numery czasopisma PTN Neofilolog), w których znajda się wybrane teksty powstałe na podstawie wykładów i referatów wygłoszonych podczas konferencji.

Sebastian Piotrowski (KUL, PTN Lublin) 


\section{DEKLARACJA CZLONKOWSKA}

Niniejszym proszę o przyjęcie mnie w poczet członków

POLSKIEGO TOWARZYSTWA NEOFILOLOGICZNEGO

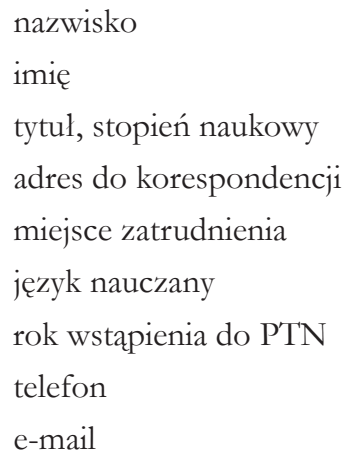

Oświadczam, że:

- $\quad$ znany mi jest Statut PTN i akceptuje jego postanowienia (zob. http://www.poltowneo.org),

- $\quad$ zobowiązuję się do corocznego uiszczania składki członkowskiej,

- $\quad$ wyrażam zgodę (nie wyrażam zgody/* na umieszczenie mojego nazwiska na stronie www PTN w Internecie,

- $\quad$ wyrażam zgodę / nie wyrażam zgody/* na umieszczenie mojego nazwiska i adresu internetowego na stronie www PTN w Internecie.

* niepotrzebne skreślić

data / podpis

Składka członkowska za rok 2009 wynosi 20 zł dla doktorantów i studentów, 40 zł dla nauczycieli, 80 zł dla członków zbiorowych.

Konto PTN: SBL Oddział Poznań 44904310702070001663020001

Wypełnioną deklarację wraz z dowodem wpłaty prosimy przesłać na adres siedziby PTN (deklarację członkowską można wypełnić na stronie www).

Polskie Towarzystwo Neofilologiczne Zarząd Główny

Collegium Novum UAM

al. Niepodległości 4, pokój 014

61-874 Poznań

adres internetowy: http:/ /www.poltowneo.org 